\title{
研 究速一報
}

\section{On Two Modifications of Nickel Oxide}

\section{By Yasumitsu Shimomura and Zenji Nishiyama}

(The Intitute of Scientific and Industrial Research,
Ôzaka University, Sakai, Japan.

Accordin $x_{3}$ to the literatures(1) which arrired reently in Japan, H.P. Roosby found that nickel oxide (NiO) has a rhombihedral structue. This faot agrees with our-experiment(2) which.was carried out without knowing his result. The cubic modification (rock-salt type), as was believed before, was also found to exist in some cases of our experiment.

For samples" were used chiefly the nickel oxides formed by heating nickel nitrate $\left(\mathrm{Ni}^{\prime}\left(\mathrm{NO}_{3}\right)_{2} 6 \mathrm{H}_{2} \mathrm{O}\right)$ in the air, and occasionally the oxide films formed on metallic nickel by heating were used. In order to determine the crystal struciure, X-ray diffraction cameras of two types, Debye-Scherrer (dia.=6cm) and focussing back reflection (dia. $=8 \mathrm{~cm}$ ), were employed, iron, cobalt, nickel and copper radiations being used for the $\{400\},\{420\},\{422\}$ and $\{511\}\{333\}$ reflections, respectively.

The difference of the new crystal structure from the rocksalt type was observed as splitting of

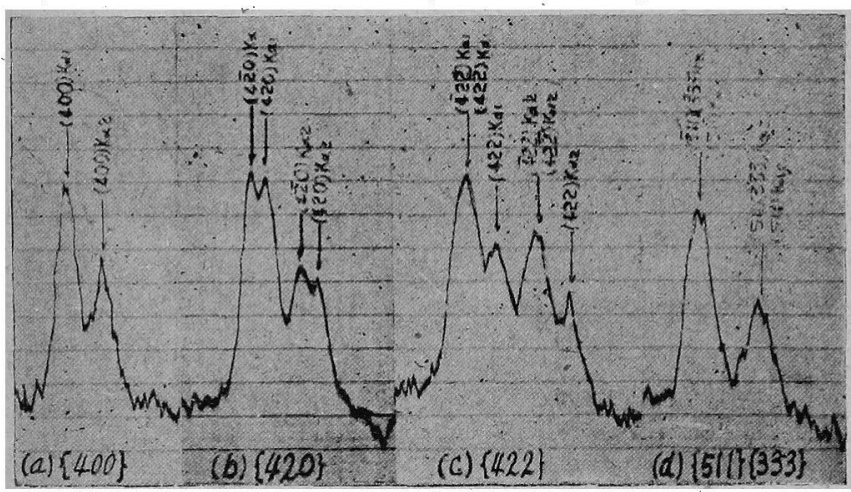

Fia. 1 Microphotometer Curves of Diffract.on Lines of the Oxide Obtained by Heating Nitrate at $1350^{\circ}$ Cfor an Four.

These values are consistent with Rooksby's results, $\alpha=2.945^{9} \AA, \alpha=63^{2} 4.2^{\prime}$ ,t $20^{\circ} \mathrm{C}$.

Thus the deviation from the cubic structure is very slight. :This fact indicates that both structures are not racally different, but that one of the may be formed from the other by a slight modification of the lattice probably originating from the Jattice defects characteristic to the oxide.

In some cases, the lines were only diffused but not splitted, and the structure in the se cases can be interpreted to be cubic. Which of the two modifications cubic or rhomb hedral, is produced depends upon the condition of formation. In the case of nitrate, it was zomewhat complicated and has not yet been determined. In the case of metallic nickel, it was comparatively simple. When the oxide film was very thin and the diffusion of nickel atoms from the substratum into the film was possible to take place, the structure if the oxide was cubic; but when the film became thick, its structure was different from the cubic, that is, a new separated line did appear. The thicker the rxicle film, the stronger became thein tensity of this separated line, and thus it was strongest when the diffusion was perfectly interrupted owing to splitting of the oxide film from the substratum during the

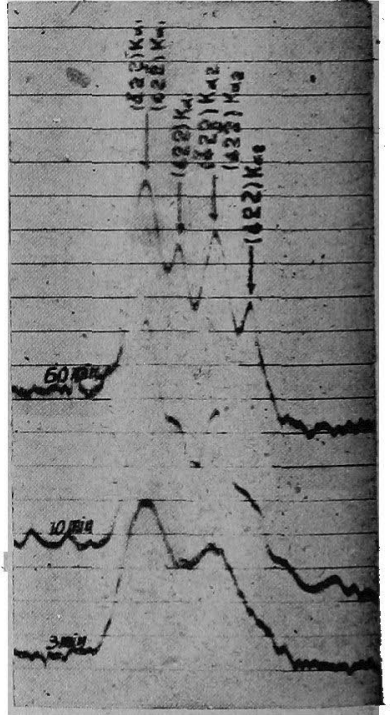

Fig. 2 Microphotmeter Curves of $\{422\}$ Limes of the Oxides Obtained by Heating $\mathrm{Ni}$-Fuils(0:0 $1 \mathrm{~mm}$ in Thickness) at $1330^{\circ} \mathrm{C}$.
(1) Chim. Abst., 38(1944), 2886; H. P. Rooksby, Nature, 160 (1947), Jui, 5.

The present writers, unfortunately, have no opportunity to receive his detailed report: H. P. Rooksby, N ature,

152(1943), 304.
(2) A paper was" read before the meeting of Nippun Kinzoku Gakkai (the Japan Institute of Jetals) held at Tokjo in Ap ril. 1948.

The outline is written in N. K. G. 12 (1948), No.1, 12 . The first"report, "On the Lattice Defect in Nicke" Oxide", was presented to 'SCAP on April 22,1948 
oxidation or to the complete consumption of metalic nickel by the "xidation. In spite of such intensity change, the a munt of the separation was not increased but was rather decreased (T.able 2 and Fig. 2).

Table! Nickel Oxide frum Nitrate

\begin{tabular}{|c|c|c|c|c|c|c|}
\hline$\{h k l\}$ & $\begin{array}{l}\text { No. of } \\
\text { Lines }\end{array}$ & $\begin{array}{l}\text { Intensity } \\
\text { Ratio }\end{array}$ & \multicolumn{2}{|c|}{ Spacing (̊) } & $\begin{array}{c}\text { Temperature } \\
\left({ }^{\circ} \mathrm{C}\right)\end{array}$ & $\begin{array}{l}\text { Separation } \\
\text { by } K_{a 1}\end{array}$ \\
\hline$\{400\}$ & 1 & - & \multicolumn{2}{|c|}{$1.04189 \pm 4$} & $7 \sim 12$ & - \\
\hline$\{420\}$ & 2 & $1: 1$ & $0.9324 \pm 2$ & $0.9315 \pm 2$ & 21 & $10.0^{\prime}$ \\
\hline$\{422\}$ & 2 & $3: 1$ & $0,85088 \pm 2$ & $0.84993 \pm 7$ & 9 & 15.91 \\
\hline$\{511\}\{333\}$ & 1 & - & \multicolumn{2}{|c|}{$0.80224 \pm 3$} & 14 & - \\
\hline
\end{tabular}

Table 2

\{422\} Lines of the Oxides Obtained by Heating

Nickel Foils $(0.01 \mathrm{~mm}$ in Thickness $)$ at $1300^{\circ} \mathrm{C}$.

\begin{tabular}{|c|c|c|c|c|c|}
\hline \multirow{2}{*}{$\begin{array}{l}\text { Heating } \\
\text { Period } \\
\text { (min) }\end{array}$} & \multicolumn{2}{|c|}{ Spacing (§) for } & \multirow{2}{*}{$\begin{array}{r}\text { Intensity } \\
\text { Ratio }\end{array}$} & \multirow{2}{*}{ Sharpness } & \multirow{2}{*}{$\begin{array}{l}\text { Degree of } \\
\text { Consumption }\end{array}$} \\
\hline & Low 0 & High $\theta$ & & & \\
\hline 3 & 0.8514 & 0.8470 & $20: 1$ & Very Diff. & Very Iittle \\
\hline 5 & 0.8513 & 0.8500 & $10: 1$ & Diffuse & Littie \\
\hline 10 & 0.8512 & 0.8502 & $5: 1$ & Sightiy Diff. & Partially \\
\hline 40 & 0.8511 & 0.8502 & $3: 1$ & Sharp & Completely \\
\hline 60 & 0.8511 & 0.8502 & $3: 1$ & Sharp & Completeiy \\
\hline
\end{tabular}

The details wili be shortiy published in the Memorier of the Institute of Scientific and Industrial Research of the Ôsaka University

\section{磁究 \\ 鐵一アルミニウム合金に於ける \\ 規則格子の本性に關する一考察}

里

洋

Hiroshi Sato : A Note on the Nature of the Superlattice Formation in Fe-Al Alloys. " Many anomalous physical properties are experimentally obserred during the superlattice formation in Fe-Al alloys. Such anomalies have not jet been completely explained in spite of extensive researches.

According to the author's investigation about the ferromagretic superlattice, sabb anomalies must be due to the interrelations between the superlattice formation ard the origination of the spontaneous magnetization. The origin of the singular properties of Fe-Al gyetem can als be reduced to this fundamental idea.

With this gereral point of view, the phase diagram concerning superlatice formation in these binary alloys are reviewed.

(Received August 24, 1948)

\section{I. 緒論}

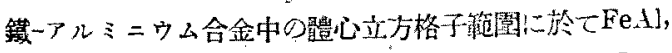

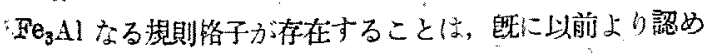
られて居り，そのX缐的研究侍特:Bradley, Jay (1) 及び

* 東北大學金屬材料研究所

(1) A. J. Bradley, A. H. Jay, Proc. Roy. Soc. A., 136 (1932), 210; J. Iron and Steel Inst., 125 (1932),339.

(2) 大濢，村四，本誌，5(1941)，259.

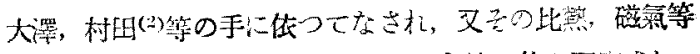
との潞係こついては Sykes, Evans(3)等に体り研究され。 比較的良く研究されたた规則格子の一つでする. 双 $\mathrm{Fe}_{3}$ 土近

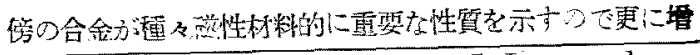

(3) C. Sykes, J. W. Bamffylde; J. Iron and Steel Inst, 130 (1934), 389.

C. Sykes, H. Evans, Proc. Roy, Soc. A., 145 (1934), 524; J. Iron and Stee] Inst., 131 (1935), 225. 